\title{
Deteksi Cepat Fusarium sp. pada Benih Kedelai Menggunakan Metode Spektroskopi Fluoresens
}

\section{Rapid Detection Method for Fusarium sp. on Soybean Seed Using Fluorescence Spectroscopy Method}

\author{
Djoko Pujiarto, Bonny Poernomo Wahyu Soekarno*, Akhiruddin Maddu \\ Institut Pertanian Bogor, Bogor 16680
}

\begin{abstract}
ABSTRAK
Patogen terbawa benih kedelai dapat menjadi sumber penyakit tanaman di lapangan. Salah satu langkah untuk mencegah risiko akibat patogen terbawa benih ialah melalui uji kesehatan benih. Salah satu potensi teknologi yang dapat dikembangkan ialah menggunakan metode deteksi spektroskopi fluoresens. Penelitian ini bertujuan mengembangkan protokol deteksi cepat cendawan patogen terbawa benih menggunakan spektroskopi fluoresens. Hasil penelitian menunjukkan bahwa metode ini dapat mendeteksi emisi fluoresens metabolit Fusarium sp. yang diinkubasi selama 24 jam. Metabolit Fusarium sp. menghasilkan fluoresens cyan pada puncak panjang gelombang emisi $504 \mathrm{~nm}$ ketika dipapari sinar laser violet (405 nm). Fusarium sp. mempunyai spektrum emisi fluoresens yang berbeda dengan spektrum emisi fluoresens medium dekstrosa kentang cair $(502 \mathrm{~nm})$. Dengan demikian metode spektroskopi fluoresens dapat digunakan sebagai metode deteksi cepat cendawan patogen terbawa benih.
\end{abstract}

Kata kunci: emisi fluoresens, patogen terbawa benih, sinar laser violet, uji kesehatan benih

\begin{abstract}
Seed borne pathogens play an important role as source of inoculum for disease in the field. Seed health testing is applied in order to prevent risks caused by seed borne pathogen. Fluorescence spectroscopy is a potential technology to be used as detection method for seed borne pathogen. Research was conducted to develop rapid detection protocol for seed borne pathogenic fungus by fluorescence spectroscopy method. The result showed that fluorescence spectroscopy could detect fluorescence emission of metabolite of Fusarium sp. after soybean seeds were incubated for $24 \mathrm{hr}$. Metabolite of Fusarium sp. produced cyan fluorescent at peak wavelength emission $504 \mathrm{~nm}$ when excited to violet light $(405 \mathrm{~nm})$. Fusarium sp. displayed typical fluorescence emission spectra which differ from fluorescence emission spectra of growth medium potato dextrose broth (PDB) $(502 \mathrm{~nm})$. It was evidenced that fluorescence spectroscopy method can be used to detect pathogenic seed borne fungi.
\end{abstract}

Key word: fluorescence emission, seed borne pathogen, seed health testing, violet light

*Alamat penulis korespondensi: Departemen Proteksi Tanaman, Fakultas Pertanian, Institut Pertanian Bogor. Jalan Kamper, Kampus Darmaga IPB, Bogor 16680.

Tel : 0251-8629364,Faks : 0251-8629362; surel : bonnypws@gmail.com 


\section{PENDAHULUAN}

Kedelai (Glycine max) merupakan komoditas pokok dan sumber protein nabati di Indonesia. Kebutuhan nasional kedelai mencapai 2.5 juta ton per tahun, namun hanya 30\% kebutuhan dapat dipenuhi oleh produksi dalam negeri (BPS 2016). Penurunan produktivitas kedelai disebabkan beberapa faktor, salah satunya cendawan Fusarium sp. sebagai patogen terbawa benih. Infeksi Fusarium sp. dapat terjadi pada saat panen, penyimpanan, dan pemasaran dengan tingkat infeksi berturut-turut mencapai 22.5-27.5\%, 34-50\%, dan 28-29\% (Ramesh et al. 2013). Cendawan Fusarium yang sering ditemukan pada benih kedelai ialah $F$. oxysporum, $F$. semitectum dan $F$. sporotrichioides (Levic et al. 2012).

Pengujian kesehatan benih perlu dilakukan untuk mencegah dan mengurangi patogen terbawa benih. Metode spektroskopi fluoresens mempunyai keunggulan untuk dikembangkan sebagai metode cepat deteksi dan identifikasi cendawan terbawa benih. Metode ini bekerja berdasarkan pada pancaran emisi fluoresens dari senyawa metabolit yang dihasilkan oleh cendawan setelah terpapar oleh panjang gelombang tertentu. Emisi yang dipancarkan oleh setiap metabolit biasanya bersifat spesifik. De Champrode et al. (2007) menyatakan bahwa uji menggunakan fluoresens merupakan metode yang murah, selektif, sensitif, dan akurat. Penelitian ini bertujuan mengembangkan protokol deteksi cepat cendawan Fusarium sp. sebagai patogen terbawa benih menggunakan metode spektroskopi fluoresens.

\section{BAHAN DAN METODE}

\section{Uji Kesehatan Benih}

Benih kedelai yang digunakan ialah benih kedelai varietas Grobogan yang diperoleh dari Unit Pengelola Benih Sumber, Balai Penelitian Aneka Kacang dan Umbi, Kabupaten Malang, Provinsi Jawa Timur. Benih tersebut berasal dari sentra benih kedelai di Jawa Timur dan sudah melalui proses sortasi dan sertifikasi sehingga memenuhi syarat untuk digunakan sebagai benih.

Pengujian dilakukan mengikuti metode kertas bloter Mathur dan Kongsdal (2003). Benih disterilkan permukaannya menggunakan $\mathrm{NaOCl} 1 \%$ selama 1 menit, dibilas air steril 3 kali dan dikeringanginkan. Sebagai kontrol digunakan benih yang tidak disterilkan. Sebanyak 200 benih (25 benih per cawan) diinkubasi pada suhu ruang selama 24 jam dengan penyinaran lampu sinar ultraviolet (NUV) 12 jam terang dan 12 jam gelap. Inkubasi dilanjutkan pada ruang dengan suhu $-20{ }^{\circ} \mathrm{C}$ selama 24 jam tanpa sinar NUV. Benih diinkubasi kembali pada suhu ruang dengan penyinaran NUV 12 jam terang dan 12 jam gelap sampai hari ke-7. Pengamatan dilakukan terhadap persentase infeksi dengan rumus:

Tingkat infeksi $=\frac{\sum \text { benih terinfeksi }}{\sum \text { benih inkubasi }} \times 100 \%$

Cendawan dengan tingkat infeksi tertinggi diisolasi dan dimurnikan pada medium agaragar dekstrosa kentang (ADK) dan diinkubasi selama 5-7 hari pada suhu ruang. Cendawan ini digunakan untuk uji lanjut sebagai cendawan target. Cendawan diidentifikasi berdasarkan karakter koloni dan morfologi cendawan mengikuti kunci identifikasi Watanabe (2002).

\section{Pengukuran Panjang Gelombang Metabolit Emisi Cendawan Target}

Produksi metabolit cendawan diukur mengikuti metode Margino (2008) yang dimodifikasi waktu inkubasinya (7 hari menjadi 15 hari). Sebanyak 2 target potongan isolat cendawan yang mempunyai tingkat infeksi tertinggi dimasukkan ke dalam $100 \mathrm{~mL}$ medium larutan dekstrosa kentang (LDK), kemudian diinkubasi selama 15 hari pada suhu ruang sambil digoyang dengan kecepatan $120 \mathrm{rpm}$. Suspensi medium disentrifugasi dengan kecepatan 6000 rpm selama 15 menit. Supernatan metabolit cendawan target yang diperoleh disaring 2 kali, pertama menggunakan filter sempit (syringe filter) berukuran $0.45 \mu \mathrm{m}$ dan penyaringan kedua yang berukuran $0.2 \mu \mathrm{m}$. 


\section{Kalibrasi Spektroskopi Fluoresens Metabolit Cendawan Target sebagai Metabolit Standar}

Metabolit Fusarium sp. yang dihasilkan diencerkan berseri pada konsentrasi $10^{-1}$ sampai $10^{-10}$. Masing-masing metabolit standar hasil pengenceran diukur panjang gelombang emisinya menggunakan spektrofluorometer (Prasetya 2008).

\section{Aplikasi Spektroskopi Fluoresens untuk Deteksi Fusarium sp. pada Benih dengan Inokulasi Buatan}

Suspensi massa konidium Fusarium sp. dengan kepadatan $10^{8} \mathrm{sel} \mathrm{mL}^{-1}$ diperoleh dari isolat Fusarium sp. yang diinkubasi selama 7 hari pada medium ADK. Biakan Fusarium sp. dihomogenkan dengan air steril sebanyak $50 \mathrm{~mL}$. Kepadatan konidium Fusarium sp. dihitung menggunakan hemositometer. Suspensi massa konidium Fusarium sp. digunakan untuk inokulasi pada benih kedelai dengan cara perendaman.

Benih kedelai direndam di dalam $\mathrm{NaOCl} 1 \%$ selama 1 menit dan dibilas 3 kali menggunakan air steril selama 1 menit. Inokulasi Fusarium sp. dilakukan dengan perendaman benih kedelai dalam suspensi massa konidium Fusarium sp dengan kerapatan $10^{8}$ sel $\mathrm{mL}^{-1}$ selama $0,5,10,15$ dan 20 menit, kemudian dikeringanginkan sampai kadar airnya mencapai $10 \%$. Benih kedelai dieksitasi dengan sinar laser violet (405 nm) untuk menentukan pendaran emisi cahaya dari metabolit cendawan. Panjang gelombang emisi fluoresens metabolit Fusarium sp. pada benih kedelai diukur menggunakan spektrofluorometer USB 4000-FL.

\section{Aplikasi Spektroskopi Fluoresens untuk Deteksi Fusarium sp. pada Benih Tanpa Inokulasi Buatan}

Benih kedelai dimasukkan ke dalam $10 \mathrm{~mL}$ medium LDK pada konsentrasi $0 \%, 25 \%$, $50 \%$, dan 100\%; lalu diinkubasi selama 24 jam pada suhu ruang sambil digoyang dengan kecepatan 120 rpm. Suspensi medium disentrifugasi dengan kecepatan $6000 \mathrm{rpm}$ selama 15 menit untuk mendapatkan supernatan metabolit cendawan target. Supernatan disaring 2 kali menggunakan syringe filter berturut-turut dengan ukuran $0.45 \mu \mathrm{m}$ dan $0.2 \mu \mathrm{m}$. Sebanyak $1 \mathrm{~mL}$ metabolit yang dihasilkan digunakan untuk pengukuran dalam spektrofluorometer USB 400-FL pada panjang gelombang eksitasi $405 \mathrm{~nm}$.

\section{HASIL}

\section{Kesehatan Benih Kedelai}

Uji kesehatan benih kedelai varietas Grobogan menghasilkan 7 jenis cendawan dengan tingkat infeksi berbeda. Infeksi paling tinggi ialah Fusarium sp. (Tabel 1). Selanjutnya Fusarium sp. digunakan sebagai cendawan model untuk uji lanjut.

\section{Panjang Gelombang Emisi Metabolit Fusarium sp.}

Metabolit Fusarium sp. pada medium LDK menghasilkan panjang gelombang emisi $504 \mathrm{~nm}$ (Gambar 1) dan memiliki spektrum warna cyan, sedangkan medium LDK kontrol menghasilkan emisi pendar hijau (green fluorescence) pada panjang gelombang emisi $502 \mathrm{~nm}$ (Gambar 2).

Pengenceran berseri metabolit Fusarium sp. dilakukan untuk mengetahui panjang gelombang emisi fluoresens pada batas minimum konsentrasi metabolit. Panjang gelombang metabolit pada pengenceran berseri $10^{-1}-10^{-6}$ menghasilkan panjang gelombang emisi $504 \mathrm{~nm}$; sedangkan pada pengenceran $10^{-7}-10^{-10}$ menghasilkan panjang gelombang emisi 476-502 nm (Gambar 3). Tidak semua konsentrasi metabolit yang

Tabel 1 Tingkat infeksi beberapa cendawan pada benih kedelai varietas Grobogan.

\begin{tabular}{lc}
\hline Jenis Cendawan & $\begin{array}{c}\text { Tingkat infeksi } \\
(\%)\end{array}$ \\
\hline Fusarium sp. & 49 \\
Aspergillus niger & 36 \\
Aspergillus flavus & 28 \\
Rhizopus sp. & 16 \\
Trichoderma sp. & 10 \\
Curvularia sp. & 3 \\
Penicillium $\mathrm{sp}$. & 3 \\
\hline
\end{tabular}


diencerkan mempunyai panjang gelombang emisi yang sama dengan metabolit Fusarium sp. dibandingkan dengan sebelum dilakukan pengenceran $(504 \mathrm{~nm})$.

Panjang gelombang emisi metabolit Fusarium sp. pada benih kedelai yang diinokulasi buatan dengan perendaman menggunakan suspensi massa konidium Fusarium sp. selama 15 menit dan 20 menit menghasilkan panjang gelombang emisi sebesar $504 \mathrm{~nm}$. Begitu pula pada benih kedelai tanpa inokulasi buatan yang diinkubasi pada medium LDK selama 24 jam hasilnya sama (Gambar 4). Panjang gelombang emisi metabolit Fusarium sp. pada benih kedelai yang diinokulasi buatan, benih kedelai tanpa inokulasi buatan, dan metabolit Fusarium sp. yang belum diencerkan atau telah diencerkan sebagai dasar kalibrasi menunjukkan panjang gelombang emisi yang sama dan konsisten.

\section{PEMBAHASAN}

Cendawan yang paling dominan menginfeksi benih kedelai varietas Grobogan ialah Fusarium sp. dengan tingkat infeksi 49\%. Fusarium sp. dapat menyebabkan penyakit rebah semai yang dicirikan kedelai akan membusuk sebelum muncul di tanah atau pangkal dan batang yang muncul di permukaan tanah akan membusuk sehingga tanaman akan rebah.

Intensitas fluoresens adalah jumlah foton yang diemisikan per unit waktu (s) per unit

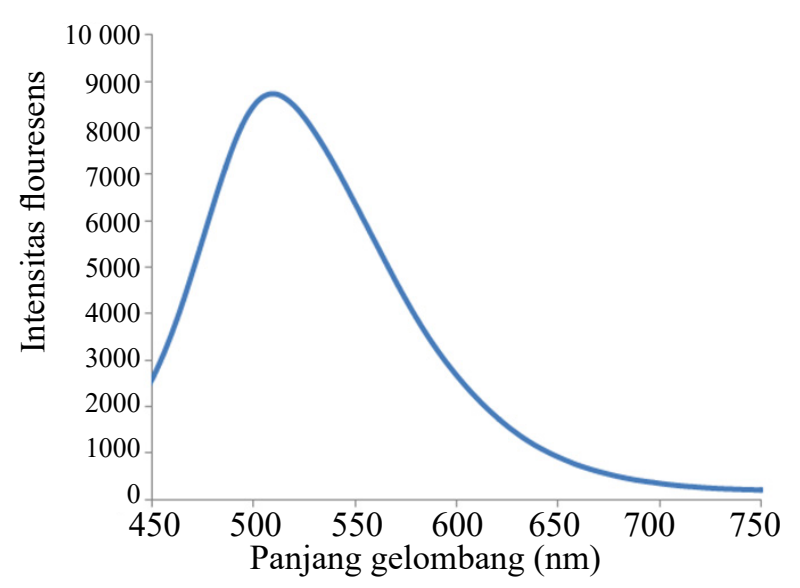

Gambar 1 Spektrum emisi fluoresens metabolit yang dihasilkan Fusarium sp. volume larutan (L) yang dinyatakan dalam mol atau ekuivalensinya dalam Einstein, jika 1 Einstein itu sama dengan 1 foton mol. Deteksi dan identifikasi metabolit Fusarium sp. menggunakan medium LDK menghasilkan intensitas fluoresens yang bervariasi, yaitu antara 2000 dan 28000 mol.

Intensitas fluoresens yang terukur pada saat pengukuran panjang gelombang emisi metabolit Fusarium sp. memberikan gambaran

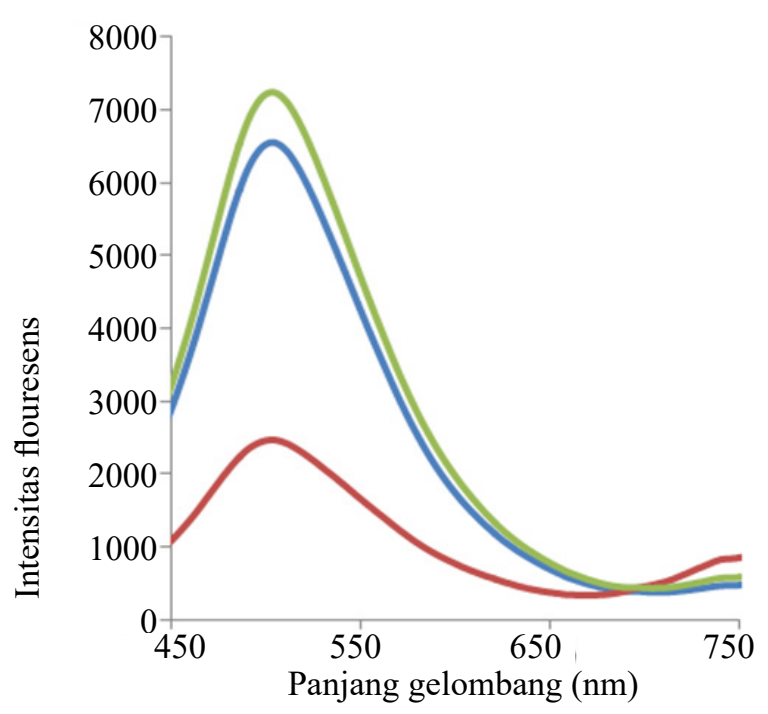

Gambar 2 Spektrum emisi fluoresens medium larutan dekstrosa kentang pada konsentrasi $25 \%$ (-), $50 \%$ (-), dan 100\% (-).

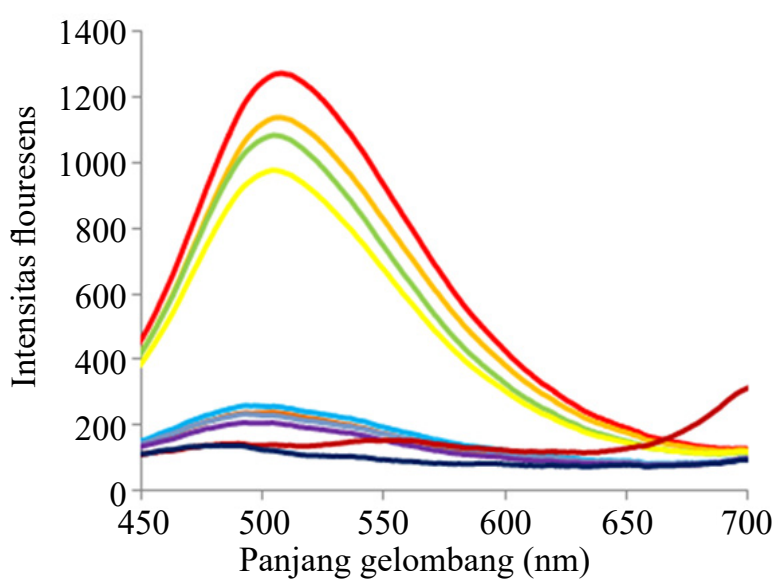

Gambar 3 Spektrum emisi fluoresens metabolit Fusarium sp. hasil beberapa pengenceran berseri menghasilkan panjang gelombang $504 \mathrm{~nm}\left(-, 10^{-1} ;-, 10^{-2} ;-, 10^{-3}\right.$;,$- 10^{-4}$; ,$\left.- 10^{-5} ;-, 10^{-6}\right)$ dan panjang gelombang $476-502 \mathrm{~nm}\left(-, 10^{-7} ;-, 10^{-8} ;\right.$ -, $10^{-9}$; ,$\left.- 10^{-10}\right)$. 


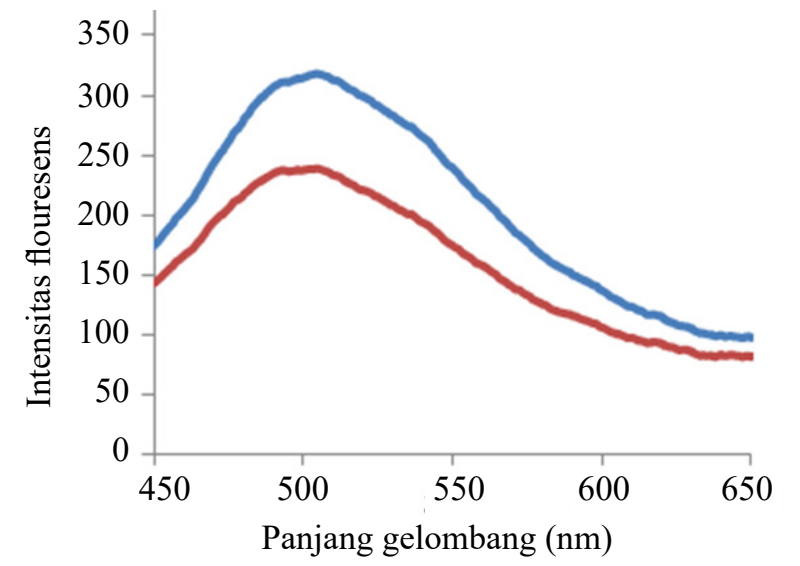

a

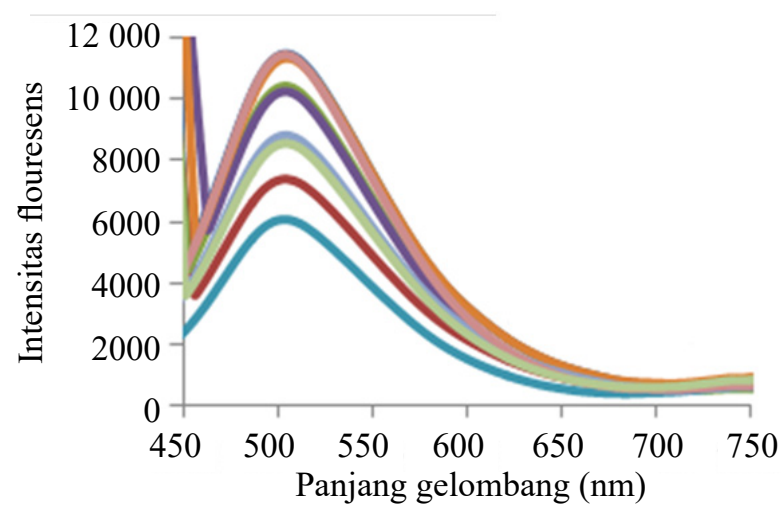

c

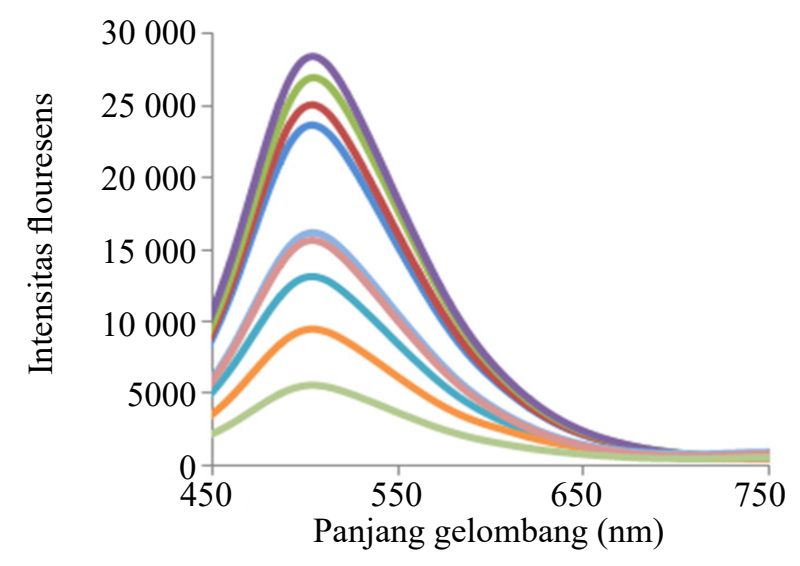

b

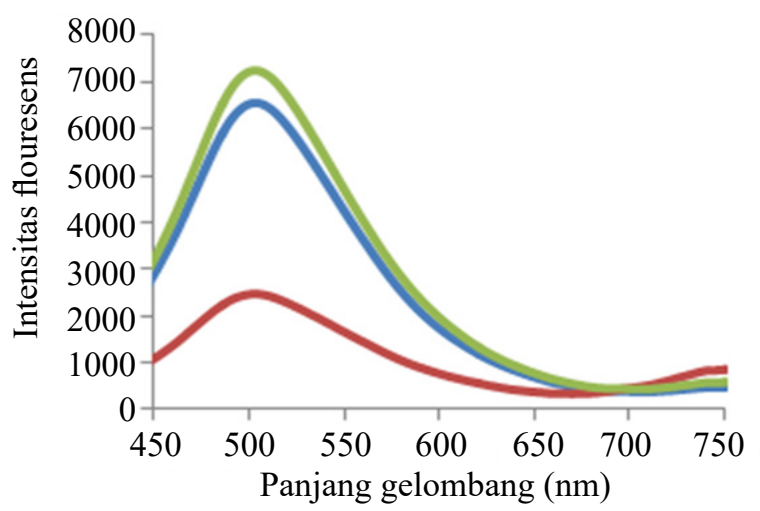

d

Gambar 4 Spektrum emisi fluoresens pada benih kedelai. a, Benih direndam dalam suspensi Fusarium sp. selama 15 menit (-) dan 20 menit (-); b, benih direndam dalam LDK konsentrasi 100\% (- sampel 2), (- sampel 4), (- sampel 5), (- sampel 6), (- sampel 7), (- sampel 8), (- sampel 10), (- sampel 15), (- sampel 16); c, Benih direndam dalam LDK konsentrasi 50\% ( sampel 5), ( sampel 6), ( sampel 8), ( sampel 10), ( sampel 11), ( sampel 14), ( sampel 15), ( sampel 16), ( sampel 18); d, Benih direndam dalam LDK konsentrasi $25 \%$ (— sampel 5), (— sampel 13), (— sampel 19) selama 24 jam.

bahwa metabolit yang telah mengalami pengenceran mengalami penurunan intensitas fluoresens. Semakin sedikit kandungan metabolit maka semakin rendah intensitas fluoresens, tetapi panjang gelombang emisi fluoresens tetap konsisten. Intensitas fluoresens semakin kecil jika suatu molekul mengandung gas oksigen. Ini terjadi karena adanya proses oksidasi yang disebabkan oleh pengaruh cahaya (fotochemically induced oxidation). Pengurangan intensitas fluoresens disebut pemadaman sendiri (quenching). Fluoresens pada molekul dipengaruhi oleh beberapa kondisi fisik, antara lain polaritas, potensial listrik, suhu, tekanan, derajat keasaman $(\mathrm{pH})$, jenis ikatan hidrogen, viskositas, dan quencher (penghambat de-eksitasi) (Bass 2000).
Deteksi dan identifikasi cendawan terbawa benih kedelai dengan metode spektroskopi fluoresens dilakukan dengan mengukur panjang gelombang emisi metabolit yang dihasilkan cendawan. Setiap metabolit yang dihasilkan cendawan terbawa benih dapat diukur panjang gelombang emisinya sampai pada panjang gelombang emisi pada titrasi dengan konsentrasi tertentu. Panjang gelombang emisi metabolit Fusarium sp. yang telah dititrasi masih terdeteksi pada titrasi ke-10-6. Aspergillus niger dan $F$. solani dapat terdeteksi dengan menggunakan spektroskopi fluoresens pada panjang gelombang emisi $424 \mathrm{~nm}$ dan $505 \mathrm{~nm}$ (Prasetya 2008, De Araujo et al. 2010). Senyawa yang dihasilkan oleh Fusarium spp. 
ialah toksin T-2, diacetoxyscirpenol, solaniol, cyclosporine $A$, pigmen tipe naftaquinon, fusalanipirone, asam fusarat, moniliformin, dan beberapa racun kimia yang belum teridentifikasi (Ishii et al. 1971; Medentsev dan Akimenko 1998; Leslie dan Summerell 2006). Fusarium juga menghasilkan senyawa golongan naftaquinon yang berfungsi sebagai racun tanaman, insektisida, antibakteri, dan fungisida. Javanicin merupakan salah satu contoh senyawa golongan naftaquinon yang mempunyai panjang gelombang emisi $504 \mathrm{~nm}$ (Medentsev dan Akimenko 1998).

Inkubasi Fusarium sp. pada medium LDK menghasilkan metabolit cendawan unik yang dapat diukur panjang gelombang emisi fluoresensnya. Aplikasi metode spektroskopi fluoresens dengan medium tumbuh LDK untuk mendeteksi keberadaan Fusarium sp. pada benih kedelai menghasilkan emisi fluoresens cyan pada panjang gelombang emisi $504 \mathrm{~nm}$. Intensitas fluoresens yang terukur dipengaruhi oleh konsentrasi metabolit yang dihasilkan oleh cendawan terbawa benih. Metode spektroskopi fluoresens dapat digunakan sebagai metode deteksi yang spesifik, cepat, dan sederhana untuk mendeteksi keberadaan Fusarium sp. dengan mengukur panjang gelombang emisi fluoresens metabolit yang dihasilkan oleh cendawan pada inkubasi benih kedelai di medium LDK selama 24 jam.

\section{UCAPAN TERIMA KASIH}

Ucapan terima kasih disampaikan kepada Badan Karantina Pertanian, Kementerian Pertanian atas dukungan dana dan fasilitas penelitian.

\section{DAFTAR PUSTAKA}

Bass D. 2000. An introduction to fluorescence spectroscopy. http://homepages.wmich. edu/rsung/files/introflour.pdf [diakses 8 Mar 2016].

[BPS] Badan Pusat Statistik. 2016. Produksi padi tahun 2015 naik 6.37 persen. Berita Resmi Statistik. Jakarta (ID): BPS.
De Champrode M, Bazzicalupo P, De Napoli L, Montesarchio D, Di Fabio G. 2007. A new competitive fluorescence assay for the detection of patulin toxin. Anal Chem. 79(2):751-757. DOI: https://doi.org/10.1021/ac0618526.

De Araujo RE, Diego J. Rativa DJ, Rodrigues MAB, Marsden A, Filho LGS. 2010. Optical spectroscopy on fungal diagnosis. Di dalam: Domenico Campolo, Editor. New Developments in Biomedical Engineering. Rijeka (HR): InTech. Hlm 447-454. http://www.intechopen.com/ books/newdevelopments-in-biomedicalengineering/optical-spectroscopy-onfungal-diagnosis [diakses 4 Sep 2016].

Ishii K, Sakai K, Ueno Y, Tsunoda H, Enomoto M. 1971. Solaniol, a toxic metabolite of Fusarium solani. Appl Microbiol. 22(4):718-720.

Leslie JF, Summerell BA. 2006. Fusarium Laboratory Manual. Iowa (US): Blackwell. DOI: https://doi. org/10.1002/9780470278376.

Levic J, Stankovic S, Krnjaja V, BocarovStancic A, Ivanovic D. 2012. Distribution frequency and incidence of seed-borne pathogens of some cereals and industrial crops in Serbia. Pestic Phytomed. 27(1):33-40. DOI: https://doi.org/10.2298/ PIF1201033L.

Margino S. 2008. Produksi metabolit sekunder (antibiotik) oleh isolat jamur endofit Indonesia. Majalah Farmasi Indonesia. 19(2):86-94.

Mathur SB, Kongsdal O. 2003. Common Laboratory Seed Health Testing Methods for Detecting Fungi. Bassedorf (CH): International Seed Testing Association.

Medentsev AG, Akimenko VK. 1998. Napthoquinone metabolite of the fungi. Pytochemistry. 47(6):935-959. DOI: $\quad$ https://doi.org/10.1016/S00319422(98)80053-8.

Prasetya A. 2008. Pengembangan metode deteksi cepat Aspergillus flavus Link. dan Fusarium sp. pada benih padimenggunakan laser-induced fluorescence [tesis]. Bogor (ID): Institut Pertanian Bogor. 
Ramesh BV, Hiremath V, Naik K, Amaresh Watanabe T. 2002. Pictorial Atlas of Soil and S, Lokesh K, Vasudevan N. 2013. Study Seed Fungi: Morphologies of Cultures of seed mycoflora of soybean from north eastern Karnataka. Karnataka J Agric Sci. 26(1):58-62. Fungi and Key to Species. Ed Ke-2. Florida (US): CRC Press LLC. 